\title{
ANALYSIS OF THE STUDENTS' ENGLISH TENSES ERRORS
}

\author{
Eko Setiawan ${ }^{1]}$, M. Fadhly Farhy Abbas ${ }^{2]}$ \\ Universitas Lancang Kuning \\ e-mail: ekosetiawan3573@gmail.com ${ }^{1]}$, fadhly@ unilak.ac.id $^{2]}$
}

\begin{abstract}
At The First Semester of English Students' Department at Faculty of Teacher Training and Education Lancang Kuning University, the researcher found that the students had a problem in had grammar error in writing. That was why researcher conducted this research that aimed toanalyze the English errors faced by the first semester of English Students Department at Faculty of Teachers Training and Education LancangKuning University.This research was Descriptive Quantitative Research. The participants of the research were 36 students. In collecting the data in this research, the researcher used test and interview as the instrument. The result of data showed that the students had 176 errors in verb tenses, 8 errors in to be, 5 errors in correct sentence and 9 in adverb of time with the percentage were $31,38 \%$ in true or false question and $27,5 \%$ in multiple choice test. In conclusion, The students had a lot of errors in applied verb tense, adverb of time, correct sentence, and to be.
\end{abstract}

\section{Keywords: Error, Grammar, English tenses}

\section{INTRODUCTION}

\subsection{Background}

In order to convey meaning in communication, both in written and oral communication, one needs to fully equipped with sufficient tenses mastery. Well-structured and understandable sentences were the clear sign of a good grammatical competence. There were two terms that are commonly used to describe the inaccuracy in applying English tenses into writing, namely error and mistake.Although English tenses have been taught to the students of

English Department since the very beginning of their education, still, English tenses errors can be found in most of their language activities, in this case writing. Basically, the English tenses errors that the students usually made were related to their negligence of basic writing mechanic and grammatical rules. The errors might seemed small and insignificant, but they might have big influences on the quality of writing. So, the researcher was interested in conducting a research entitled "An Analysis of Students' English Tenses Errors Faced by The First Semester of English Students' Department at Faculty of Teacher Training and Education Lancang Kuning University" 


\subsection{Review of Related Literatures}

Brown (2000: 7) stated that a search in contemporary dictionaries reveals that learning is the acquiring or getting of knowledge of a subject or a skill by study, experience, or instruction.

According to Gerot and Wignel (1994), grammar as a theory of language, of how language was put

According to Pardiyono (2007), tense was a variation of the change of verb form includes full verb, be and auxiliary that were usually used as predicate in the sentence, which should be appropriated with the kinds of time expression. The words tense stood for a verb form or series of verb form used to express time relation.

\section{METHOD}

This research was a Descriptive Quantitative Research. The researcher conducted the research collaboratively with English teacher to find out the problem that occur in English errors in writing. The participants of this research were the students of Faculty of Teachers Training and Education of Lancang Kuning University and the researcher took the first semester students that consists of 36 studentsThere were two kinds of instruments that will be used in this research. They were test and interview. In analyzing the data, its used descriptive analysis technique (percentage). And it also used the formula that purposed by Sudijono:2004. In the following formula: together and how it works. In addition, Abbas (2015) states grammar includes the ability to apply correct sentence structure or construction.

According to Larsen and Freeman (2000) that grammar was an important language aspect should be possessed and mastered.

$$
\mathbf{P}=\frac{\mathbf{F}}{\mathbf{N} \times 100 \%}
$$

$\mathrm{P}=$ Percentage

$F=$ Frequency of error occurred

$\mathrm{N}=$ Number of cases (total frequent / total individual)

and to know the average of error percentage, the formula used:

$$
\begin{aligned}
& \mathbf{P}=\frac{\mathbf{F}}{\mathbf{N}+\mathbf{n x} \mathbf{1 0 0 \%}} \\
& \mathrm{P}=\text { Percentage } \\
& \mathrm{F}=\text { Frequency of error occurred } \\
& \mathrm{N}=\text { Number of cases (total frequent } / \\
& \text { total individual) } \\
& \mathrm{n}=\text { Number of item test }
\end{aligned}
$$

Morris (1979: 259) defined "Errors as an act, assertion, or belief that unintentionally deviated from what is correct, right or true. In other definitions he stated that it was the condition of having incorrect or false knowledge or the act or an instance of deviation from the acceted code of behaviour, a transgression; wrongdoing." 


\section{FINDINGS}

The true or false questions and multiple choice tests were given to the students that consist of 10 questions of true or false question which focused on simple present tense and present continuous tense. In multiple choice test, there were 20 questions focused on simple present tense, Simple past tense, Present perfect tense and future tense discussed the errors made by the first semester students of English Department of Faculty of Teachers' Training and Education.

\section{Diagram 4.1}

Total of Errors Frequency

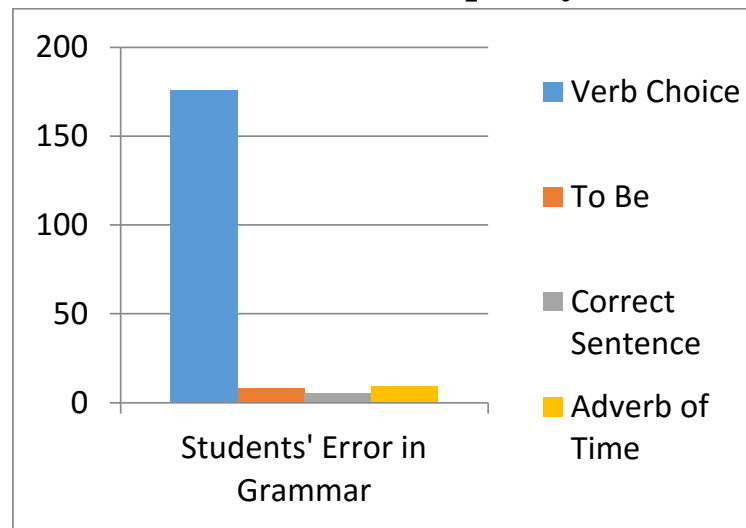

Based on the diagram 4.1, it can be interpreted that the most common type of errors made by students in using simple present tense, present continuous tense, present perfect tense, future tense and simple past tense is in Verb Tense. It is the high errors in which the students made 176 errors, 8 errors in applied to be, the students made 5 errors in correct sentence and the students also made 9 errors in choosing adverb of time.

\section{CONCLUSION}

The students had a lot of errors in applied verb tense, adverb of time, correct sentence, and to be. The researcher founds a few problems that caused of grammar error:

a. Students were not comprehend the tenses

b. Students were shy to ask more information about the tenses

\section{REFERENCES}

Abbas, M. F. F. (2015). Analysis of Students' Ability in Writing a Research Proposal. ELTLectura, 2 (2).

Berry-Luterman, Lillian, and Asher Bar. The diagnostic significance of sentence repetition for language impaired children. Journal of Speech and Hearing Disorder, vol 36, no 1, pp.29-39

Bitchener, John. 2005. The Extent to Which Classroom Teaching Options and Independent Learning Activities Can Help L2 Writers Improve the Accuracy of Their Writing. Auckland: Auckland University of Technology

Brandt, Cardine. (2009). Read, Research and Write: Academic Skills for ESL

Students in Higher Education. London: Cromwell Press. 
Brown, H. Douglas. (1994). Principles of Language Learning and Teaching. 3rd edition. Englewood Cliffs, New Jersey: Prentice Hall Inc

Brown, H. D. (2001) Teaching by Principles: An interactive approach to language

pedagogy (second edition) New York: Longman.

Celce-Murcia, M. (Ed.). 2001. Teaching English as a second or foreign language( $3 r d$ ed.). Boston, MA: Heinle \& Heinle.

Davies, P. and Pearse, E. (2002). Success in English Teaching. Shanghai: Shanghai Foreign Language Education Press.

Ellis, Rod.(1994). The Study of Second Language Acquisition. New York: Oxford University Press

Erdogan, Vacide. (2005) Contribution of error analysis to foreign language teaching.

Mersin University Journal of the Faculty of Education, 1(2), 261270

Ferris, D.R. (2002). Treatment of Error in Second Language Student Writing. Ann Arbor: University of Michigan Press.

Galasso, Joseph. (2002). Analyzing English Grammar: An Introduction to Feature Theory. California State University, Northridge..
Harmer, Jeremy. 2002. The Practice of English Language Teaching 3rd Edition., London: Longman.

Hsieh, H.F., and Shannon, S.E. (2005). Three approaches to qualitative content analysis. Qualitative Health Research, 15(9), 1277-1288.

Hidayat,Agus.2015. An Analysis Of Students' Errors In Writing Introduction Of Thesis Of English Department Students of Iain Raden Intan Lampung. Iain Raden Intan Lampung

Hourani, Taseer.M.2008. An Analysis of the Common Grammatical Errors in the English Writing made by 3rd Secondary Male Students in the Eastern Coast of the UAE. Institute of Education British University in Dubai

Iriskulov, A., T. 2006. Theoritical Grammar of English. Uzbek State World Languages University.

Komala,Lia Ratna.2014. An Analysis Of Students' Errors In Using English Tenses (A Case Study at the Second Grade Students of SMP YAPERA An-Nurmaniyah, Ciledug). Syarif Hidayatullah State Islamic University Jakarta Thesis

Larsen-Freeman Diane. 1986. Techniques and Principles in Language Teaching, English: Oxford University Press. 
Lee, I. (2004). Error Correction in L2 Secondary Writing Classrooms: The case ofHong Kong. Journal of Second Language Writing, 13(4), 285-312.

Littlewood, W. (2002). Foreign and Second Language Learning: Language Acquisition Research and Its Implications for the Classroom.

Cambridge:Cambridge University Press.

Lynch, Tony. (2008). Communication in the Language Classroom. Oxford: Oxford University Press.

Martinet and Thomson. 1986. A Practical English Grammar. New York: Oxford University Press

Novita,Rury.2014. An Analysis of Grammatical Errors In The 1st Year Students' Writings At English Department, Andalas University. English Department, Faculty of Humanities, Andalas University

Pardiyono. 2001. Bahasa Inggris 16 Tenses. Yogyakarta: Andi.

Sudijono, Anas. (2004)Pengantar Statistik Pendidikan. Jakarta: PT. Raja Grafindo Persada
Thornbury Scott. (1999). How to Teach Grammar, England: Pearson Education Limited.

Wignel and Gerot. (1994). Making Sense of Functional Grammar, Australia: Gerd Stabler. 